\title{
Tijd voor ACTIE - goud voor zilver !
}

Citation for published version (APA):

Janssen - Heijnen, M. (2017). Tijd voor ACTIE - goud voor zilver ! Maastricht University. https://doi.org/10.26481/spe.20170623mjh

Document status and date:

Published: 23/06/2017

DOI:

10.26481/spe.20170623mjh

Document Version:

Publisher's PDF, also known as Version of record

\section{Please check the document version of this publication:}

- A submitted manuscript is the version of the article upon submission and before peer-review. There can be important differences between the submitted version and the official published version of record.

People interested in the research are advised to contact the author for the final version of the publication, or visit the DOI to the publisher's website.

- The final author version and the galley proof are versions of the publication after peer review.

- The final published version features the final layout of the paper including the volume, issue and page numbers.

Link to publication

\footnotetext{
General rights rights.

- You may freely distribute the URL identifying the publication in the public portal. please follow below link for the End User Agreement:

www.umlib.nl/taverne-license

Take down policy

If you believe that this document breaches copyright please contact us at:

repository@maastrichtuniversity.nl

providing details and we will investigate your claim.
}

Copyright and moral rights for the publications made accessible in the public portal are retained by the authors and/or other copyright owners and it is a condition of accessing publications that users recognise and abide by the legal requirements associated with these

- Users may download and print one copy of any publication from the public portal for the purpose of private study or research.

- You may not further distribute the material or use it for any profit-making activity or commercial gain

If the publication is distributed under the terms of Article $25 \mathrm{fa}$ of the Dutch Copyright Act, indicated by the "Taverne" license above, 


\section{Tijd voor ACTIE - goud voor zilver!}

\section{Inaugurele rede prof. dr. Maryska Janssen-Heijnen, 23 juni 2017, Maastricht}

Geachte leden van het College van Bestuur van de Universiteit Maastricht, leden van het College van Toezicht, de Raden van Bestuur van Maastricht Universitair Medisch Centrum en VieCuri Medisch Centrum, collegae, vrienden en familie,

Graag wil ik jullie in de komende drie kwartier meenemen voor een kijkje in mijn werk en met name in de inhoud en relevantie van mijn leerstoel. Ook zal ik uitleg geven over de titel van deze rede 'Tijd voor ACTIE - goud voor zilver!'. Menigeen in dit publiek heeft hierover al gebrainstormd en zijn of haar ideeën geopperd of vragen gesteld. Tot nu toe heb ik deze reacties met veel plezier aangehoord, maar nog geen opheldering gegeven over de betekenis die ik hierbij heb. Dat zal ik in deze rede uitleggen.

In mijn dagelijks leven ben ik klinisch epidemioloog, hetgeen ook terugkomt in het eerste deel van de titel van mijn leerstoel 'Klinische epidemiologie'. Mensen vragen me vaak wat ik als epidemioloog eigenlijk doe. "Doe je onderzoek naar epidemieën, of zit je in het lab?". Epidemiologie is veel breder dan dat. Eigenlijk komt het neer op het oplossen van vraagstukken, één van mijn favoriete onderdelen op de lagere school.

De term epidemiologie is voor sommigen een moeilijk woord (zowel om te begrijpen als om uit te spreken). Als we echter kijken naar de betekenis van de samenstelling van dit woord, dan wordt het al duidelijker. Epidemie is afgeleid van de Griekse woorden 'epi' (=op/over) en 'demos' (=volk). Epidemieën zijn verschijnselen (plagen, ziekten) die als het ware op een volk (populatie) geworpen zijn. 'Logos' betekent 'leer'. Epidemiologie is de leer of de wetenschap die zich bezighoudt met de bestudering van deze verschijnselen. Epidemiologie is een soort marktonderzoek van de gezondheidszorg. Het vóórkomen van ziekten wordt beschreven in relatie tot het vóórkomen van verschijnselen die:

- mogelijk van invloed zijn op het ontstaan van de desbetreffende ziekte (risicofactoren),

- een indicatie geven voor de aanwezigheid van de ziekte (diagnostische factoren), of

- samenhangen met het verloop van de ziekte (prognostische factoren).

Het doel is om met behulp van deze kennis ziekten of gevolgen van ziekten te voorkómen (preventie) en de zorg te verbeteren.

De titel van mijn leerstoel heeft de toevoeging 'in het bijzonder Kanker bij Ouderen'.

Het percentage ouderen in de Nederlandse bevolking is de afgelopen decennia sterk gestegen. Men spreekt hierbij over vergrijzing. Het percentage 65plussers is gestegen van bijna $8 \%$ in 1950 naar ruim $18 \%$ in 2016 (bron: CBS). Het percentage 80plussers is sterk gestegen van $1 \%$ in 1950 naar $4,4 \%$ in 2016. Naar verwachting blijven deze percentages de komende 25-30 jaar nog stijgen. Dit betekent in absolute zin dat het aantal 65-plussers in de Nederlandse bevolking in de komende 25 jaar sterk stijgt van ruim 3 miljoen nu tot bijna 4,8 miljoen in

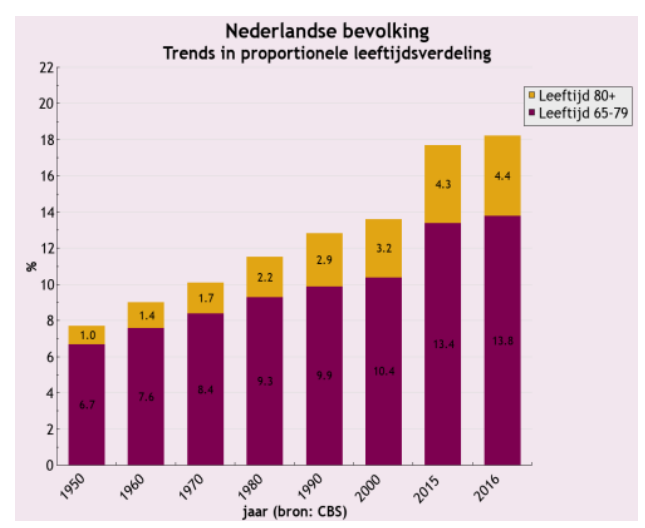
2040. Bij het aantal 80-plussers is er zelfs sprake van bijna een verdrievoudiging: van ongeveer 750.000 inwoners nu, tot ongeveer 2 miljoen in 2050 (bron: CBS). 


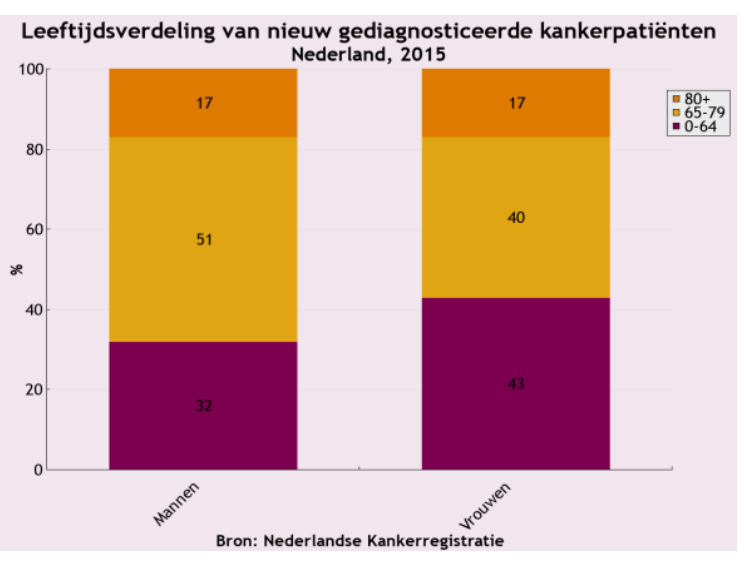

Bij patiënten die worden gediagnosticeerd met kanker is het percentage ouderen nog veel groter dan in de algemene bevolking. Van mannen bij wie de diagnose kanker wordt gesteld is bijna $70 \% 65$ jaar of ouder en bij vrouwen is dit bijna $60 \%$. Zeventien procent is zelfs 80 jaar of ouder op het moment van diagnose van kanker.

We kennen uit het nieuws allemaal de voorbeelden van speciale prestaties van zeer fitte ouderen (een paar van deze zal ik tijdens mijn rede nog de revue laten passeren), maar we kennen ook allemaal ouderen die zeer kwetsbaar zijn. Ouderen hebben vaak niet alleen kanker, maar ook nog andere ernstige chronische ziekten, zoals hart- en vaatziekten, longziekten, suikerziekte, etc. We noemen dit co-morbiditeit. 'Co' betekent 'samen/met' en 'morbiditeit' betekent 'ziekte'. Het zijn dus 'bijkomende ziekten' naast de kanker.

Dat betekent dat de behandeling van kanker bij deze patiënten veel complexer is dan bij jongere patiënten. Er kunnen interacties zijn tussen medicijnen voor de bijkomende ziekten en de antikankermiddelen. Ook is het mogelijk dat een oudere patiënt niet fit genoeg is om een bepaalde zware behandeling voor kanker te ondergaan.

De meeste richtlijnen voor behandeling van kanker zijn gebaseerd op wetenschappelijk onderzoek, waarbij verschillende behandelingen met elkaar worden vergeleken door patiënten via loting toe te wijzen aan een behandeling. We noemen dit de zogenaamde 'clinical trials'. Onder andere vanwege de verhoogde kans op complicaties, doen ouderen vaak niet mee aan dit type onderzoek. De uitkomsten van zulk onderzoek zijn dus voornamelijk gebaseerd op jongere en fittere patiënten en het is nog onvoldoende duidelijk of oudere kwetsbare patiënten ook profijt hebben van de aangewezen behandeling en hoe deze wordt verdragen.

Daarom is het van belang dat, naast clinical trials, inzicht wordt gegeven over toegepaste behandelingen, mogelijke complicaties en uitkomsten van behandeling bij oudere patiënten met kanker in de dagelijkse praktijk.

Dit kan o.a. met behulp van gegevens van het Integraal Kankercentrum Nederland (IKNL). Hiermee kunnen we bijvoorbeeld de veranderingen in overleving van patiënten met kanker in Nederland in de loop van de tijd in kaart brengen. We zien dat zowel voor jongere als oudere patiënten de 5jaarsoverleving de afgelopen decennia duidelijk is verbeterd: bij patiënten jonger dan 75 jaar van ongeveer $50 \%$ in de eerste helft van de jaren ' 90 naar bijna $70 \%$ een paar jaar geleden en bij ouderen van ruim $40 \%$ naar ruim $50 \%$. Dat is goed

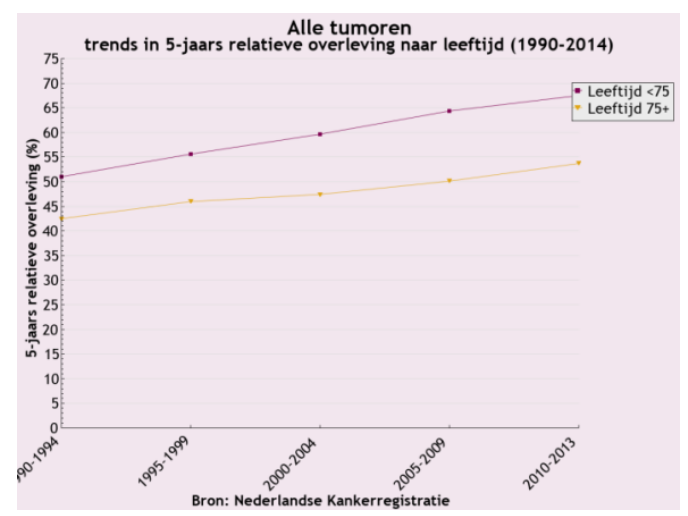
nieuws! We zien echter ook dat de 5-jaarsoverleving voor ouderen minder is gestegen dan voor jongere patiënten. Dit effect zien we nog sterker terug als we naar sommige afzonderlijke tumoren kijken. Dit is bijvoorbeeld het geval bij patiënten met een lokaaluitgebreid (stadium III) niet-kleincellig type longkanker. 


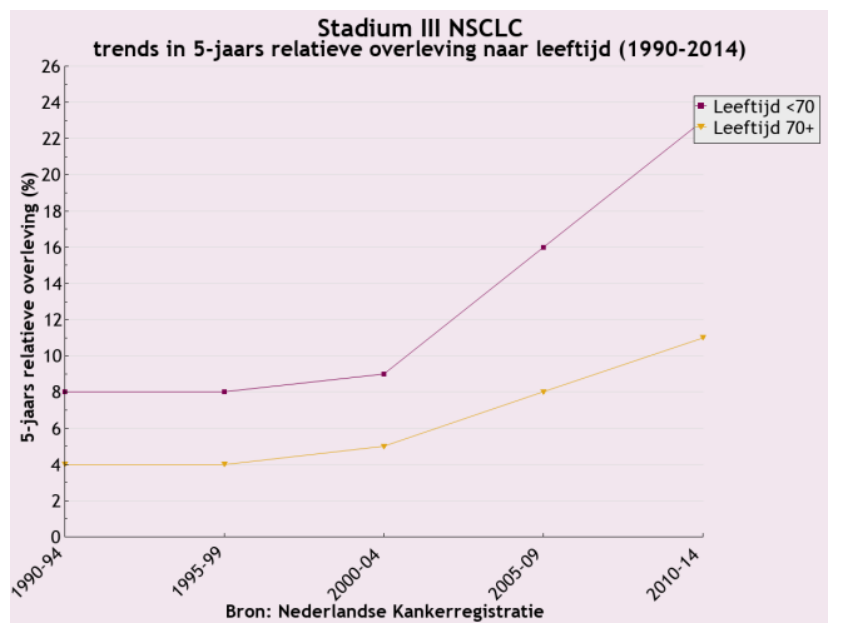

Dit liet één van mijn promovendi (Lizzy Driessen) zien in een artikel dat recent werd gepubliceerd in het tijdschrift Lung Cancer. Voor patiënten tot 70 jaar is de 5 -jaars overleving sterk gestegen sinds het begin van deze eeuw. Ook voor patiënten van 70 jaar of ouder is de 5 -jaars overleving gestegen, echter duidelijk minder sterk dan voor jongere patiënten. Dit heeft tot gevolg dat het verschil in overleving tussen oudere en jongere patiënten in de loop van de tijd alleen maar groter is geworden.

Eén van de onderliggende verklaringen is het feit dat de behandeling voor dit type kanker in de loop van de tijd is verbeterd. Tegenwoordig is gelijktijdige behandeling met chemotherapie en radiotherapie de voorkeursbehandeling die leidt tot de beste overleving bij fitte patiënten. Deze behandeling is echter zwaar en kan leiden tot ernstige complicaties. Mede om deze reden ontvangen ouderen minder vaak deze standaardbehandeling. Ik laat hierover later in deze rede meer details zien. Op deze manier hebben ouderen mogelijk minder voordeel van vooruitgang op het gebied van diagnostiek en behandeling dan jongeren.

Hiermee kom ik op het eerste deel van de titel van mijn rede, 'Tijd voor ACTIE'.

Dit is zowel letterlijk als figuurlijk bedoeld:

1. Het is de hoogste tijd voor actie.

2. Daarnaast moeten we de tijd nemen voor actie op het gebied van:

a. het goed kijken naar de héle patiënt en niet alleen naar de kanker, maar ook

b. voor het bespreken van de wensen en voorkeuren van de patiënt.

3. Tenslotte wordt het tijd dat we meer aandacht hebben voor de leefstijl van deze patiënten. Mogelijk kunnen patiënten door het aanpassen van de leefstijl een zware behandeling voor kanker beter doorstaan en herstellen ze sneller. Dat komt niet alleen de overlevingskans ten goede, maar zeker ook de kwaliteit van leven. Onderdeel hiervan is dat patiënten in actie komen, maar daar kom ik later op terug.

'Actie' is zeker van toepassing op Robert Marchand. Hij is 105 jaar oud en vestigde afgelopen januari een nieuw werelduurrecord van ruim $24 \mathrm{~km}$ fietsen in de categorie van de 105-plussers. Hij startte pas op 78jarige leeftijd met fietsen. Twee jaar eerder had hij ook al 100 kilometer gefietst in 4 uur, 17 minuten en 27 seconden: eveneens een record bij de eeuwelingen.

ACTIE is met een reden in hoofdletters geschreven. Ik zal de afzonderlijke letters punt voor punt toelichten.

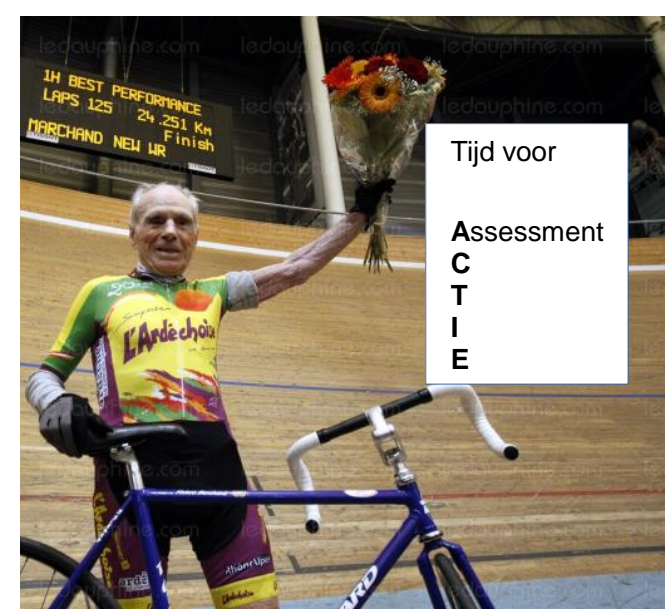


De 'A' van ACTIE staat voor 'assessment'. 'Geriatrisch assessment' is de term voor het uitgebreide onderzoek dat de klinisch geriater doet. Hoe ouder we worden, hoe unieker we ook worden. We krijgen steeds meer unieke kenmerken. De populatie ouderen bestaat dus uit personen die ieder unieke kenmerken hebben. Dit wordt ook wel heterogeniteit genoemd. Eén van mijn eerdere promovendi, Huub Maas, heeft de heterogeniteit bij oudere patiënten met kanker in kaart gebracht.

Achteruitgang in het functioneren bij ouderen wordt meestal niet veroorzaakt door één ziekte of één probleem, maar door verschillende problemen tegelijkertijd. Dit wordt vaak pas duidelijk na systematisch geriatrisch onderzoek. Dit bestaat uit zowel lichamelijk als psychisch onderzoek. Daarnaast wordt gekeken naar het functioneren evenals naar de omgeving van

Unravelling Heterogeneity in Elderly Cancer Patients

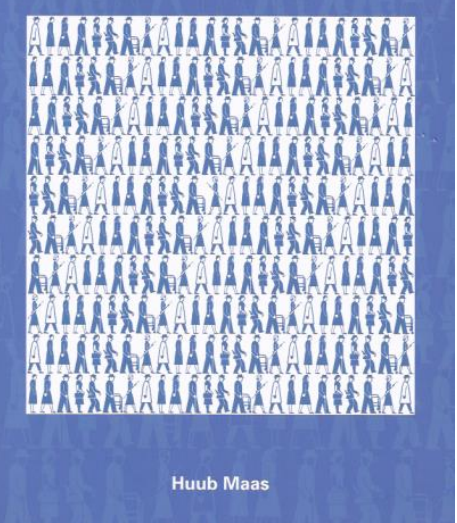
de patiënt. Een volledig geriatrisch onderzoek duurt echter ongeveer twee en een half uur. Omdat dit zo tijdrovend is, is het niet haalbaar om een uitgebreid geriatrisch assessment uit te voeren bij alle ouderen die worden gediagnosticeerd met kanker. Toch is het belangrijk om even de tijd te nemen om goed naar de totale patiënt, de omgeving en zijn/haar wensen te kijken, voordat een ingrijpende behandeling wordt gestart. Daarom is het van belang om na te gaan hoe oudere patiënten op een haalbare manier gescreend kunnen worden op kwetsbaarheid.

Helaas is er echter nog steeds onvoldoende bekend over hoe geriatrische kenmerken samenhangen met het verdragen van een behandeling voor kanker en het effect hiervan. Eén van de grote uitdagingen binnen mijn leerstoel is om te onderzoeken welke patiëntkarakteristieken kunnen voorspellen of een patiënt een bepaalde behandeling kan verdragen en wat het effect van zulke behandeling is op overleving en vooral ook kwaliteit van leven. Met behulp van deze informatie en de voorkeuren van de patiënt kan vervolgens een keuze van behandeling worden gemaakt die leidt tot een optimale balans tussen overlevingstijd en kwaliteit van leven.

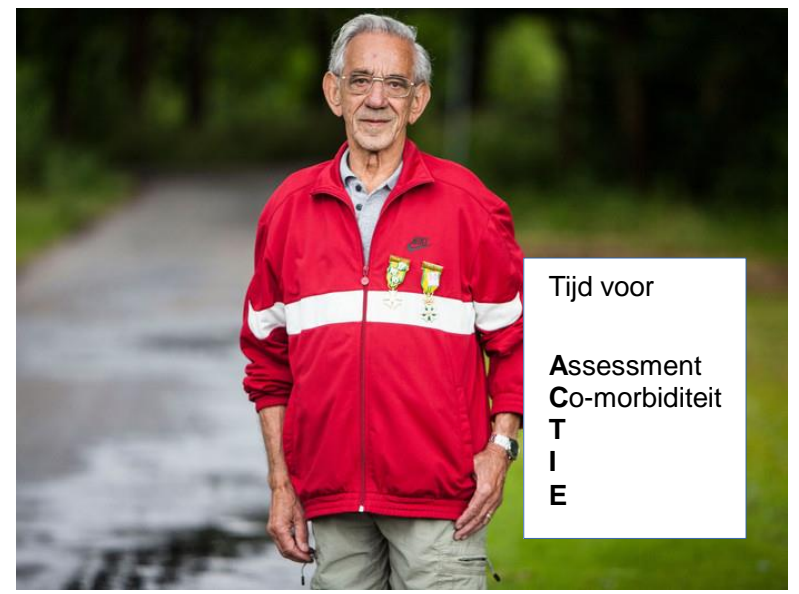

Dan komen we weer terug op 'ACTIE'. Dat is ook zeker van toepassing op Herman Dubie. Met zijn 93 jaar was hij in 2016 de oudste deelnemer aan de Nijmeegse Vierdaagse.

Eén van de belangrijke onderdelen van het geriatrisch assessment is co-morbiditeit (bijkomende ziekten). Dat brengt me bij de volgende letter van ACTIE: de C van 'comorbiditeit'.

De afgelopen decennia hebben we enorme sprongen vooruit gemaakt met betrekking tot het voorkómen en behandelen van een aantal belangrijke doodsoorzaken, zoals hart- en vaatziekten. Dat is fantastisch nieuws. Echter, deze successen hebben er ook toe geleid dat deze aandoeningen chronische aandoeningen zijn geworden. Mensen blijven dus langer leven, maar hebben vaak meerdere ernstige chronische ziekten tegelijkertijd. 
Veel oudere patiënten hebben dus naast kanker één of meer ernstige bijkomende (chronische) ziekten (co-morbiditeit). De figuur laat zien dat van de patiënten tussen 50 en 65 jaar, 28\% naast de kanker één bijkomende chronische ziekte heeft. Dit blijft ongeveer gelijk in de leeftijdsgroepen 65-79 jaar en 80 jaar en ouder. Daarnaast heeft $20 \%$ van de patiënten in leeftijdsgroep 50-64 jaar minimaal 2 bijkomende ziekten. Dit percentage stijgt sterk met de leeftijd tot $42 \%$ in leeftijdsgroep $65-79$ jaar en zelfs $54 \%$ bij

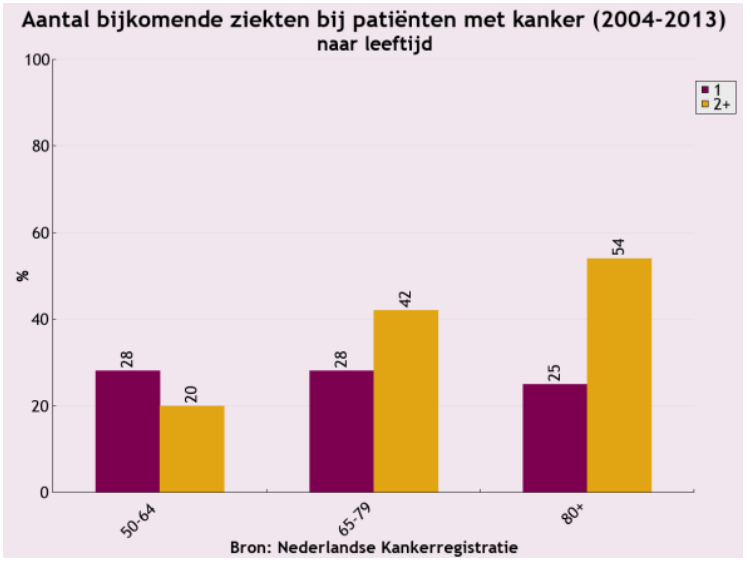
80-plussers. Dat betekent dus dat van de patiënten die in de leeftijdsgroep 65-79 jaar worden gediagnosticeerd met kanker, $70 \%$ naast de kanker nog minimaal één andere chronische ziekte heeft. Bij de 80 -plussers is dit zelfs $80 \%$ !

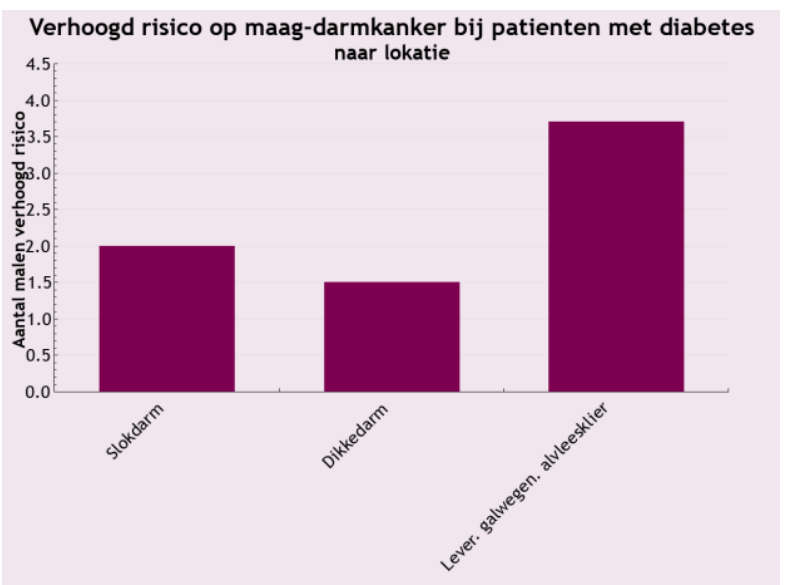

Als een bepaald type co-morbiditeit veel voorkomt bij een bepaald type kanker, dan kan dit duiden op gemeenschappelijke risicofactoren voor de bijkomende ziekte en de betreffende kanker. Zo komen bijvoorbeeld hart- en vaatziekten en chronische longziekten veel voor bij patiënten met longkanker. Dit kan worden verklaard door de gezamenlijke risicofactor roken. Twee van mijn promovendi, Sander de Kort en Roy de Jong, zijn bezig met het in kaart brengen van de relatie tussen diabetes (suikerziekte) en de behandeling hiervan enerzijds en het risico op verschillende soorten kanker van het maag-darmkanaal anderzijds. Eén van de resultaten is dat het risico op slokdarmkanker bij patiënten met diabetes ongeveer twee keer zo groot is als bij mensen zonder diabetes, het risico op dikkedarmkanker anderhalf keer zo groot en het risico op kanker van de lever, galwegen of alvleesklier zelfs bijna vier keer zo groot.

De samenhang tussen diabetes (en/of de behandeling voor diabetes) en het ontstaan van kanker is ingewikkeld. Diabetes en kanker kunnen bijvoorbeeld dezelfde risicofactoren hebben (denk aan overgewicht, weinig lichaamsbeweging, etc.), maar het kan ook zo zijn dat de effecten van diabetes (bijvoorbeeld een hogere suikerspiegel) het risico op kanker verhogen. Daarnaast heeft bepaalde medicatie voor diabetes mogelijk juist weer een risicoverlagend effect op kanker. Ook moet rekening worden gehouden met de tijd tussen de blootstelling aan de risicofactor en het ontstaan van kanker. Zo kan het zijn dat een verhoogd risico op alvleesklierkanker bij patiënten met diabetes verklaard wordt, doordat kanker in de alvleesklier (het insuline-producerend orgaan) ervoor heeft gezorgd dat diabetes is ontstaan; een omgekeerde relatie dus. Kortom, we moeten met heel veel factoren rekening houden. Het gaat te ver om dat hier allemaal uitgebreid te bespreken. Dit soort onderzoek is van belang voor preventie en vroege opsporing, en daarmee ook voor overleving en kwaliteit van leven.

Naast het feit dat co-morbiditeit een indicatie kan geven over risicofactoren, maakt het aanwezig zijn van andere ziekten naast de kanker de behandeling van kanker ook veel complexer. Mensen met co-morbiditeit zijn vaak kwetsbaar. Mogelijk kunnen patiënten met ernstige hart- en vaatziekte of chronische longziekte bijvoorbeeld geen operatie voor 
longkanker ondergaan, vanwege het hoge risico op ernstige complicaties. Ook kunnen interacties ontstaan tussen de (medicatie voor de) bijkomende ziekte en de (behandeling van de) kanker.

Een belangrijke vraag voor oncologen is of oudere patiënten een behandeling volgens de richtlijnen kunnen verdragen. Deze onzekerheid leidt enerzijds tot levensbedreigende complicaties bij patiënten die achteraf te kwetsbaar bleken voor een standaardbehandeling, maar anderzijds soms ook tot onderbehandeling van de relatief fitte oudere patiënt die de behandeling mogelijk wel had kunnen verdragen en dus effect zou kunnen hebben gehad op overleving. Artsen en patiënten zouden gebaat zijn bij een makkelijk toepasbaar hulpmiddel, waarmee een inschatting gemaakt kan worden welke patiënten het risico lopen om ernstige complicaties te ontwikkelen en welke patiënten juist voordeel kunnen hebben van een bepaalde behandeling. Dit kan ondersteunen bij de therapiekeuze en zo leiden tot een optimale balans tussen levensverlenging en kwaliteit van leven (voor ouderen is met name het behoud van zelfredzaamheid van groot belang).
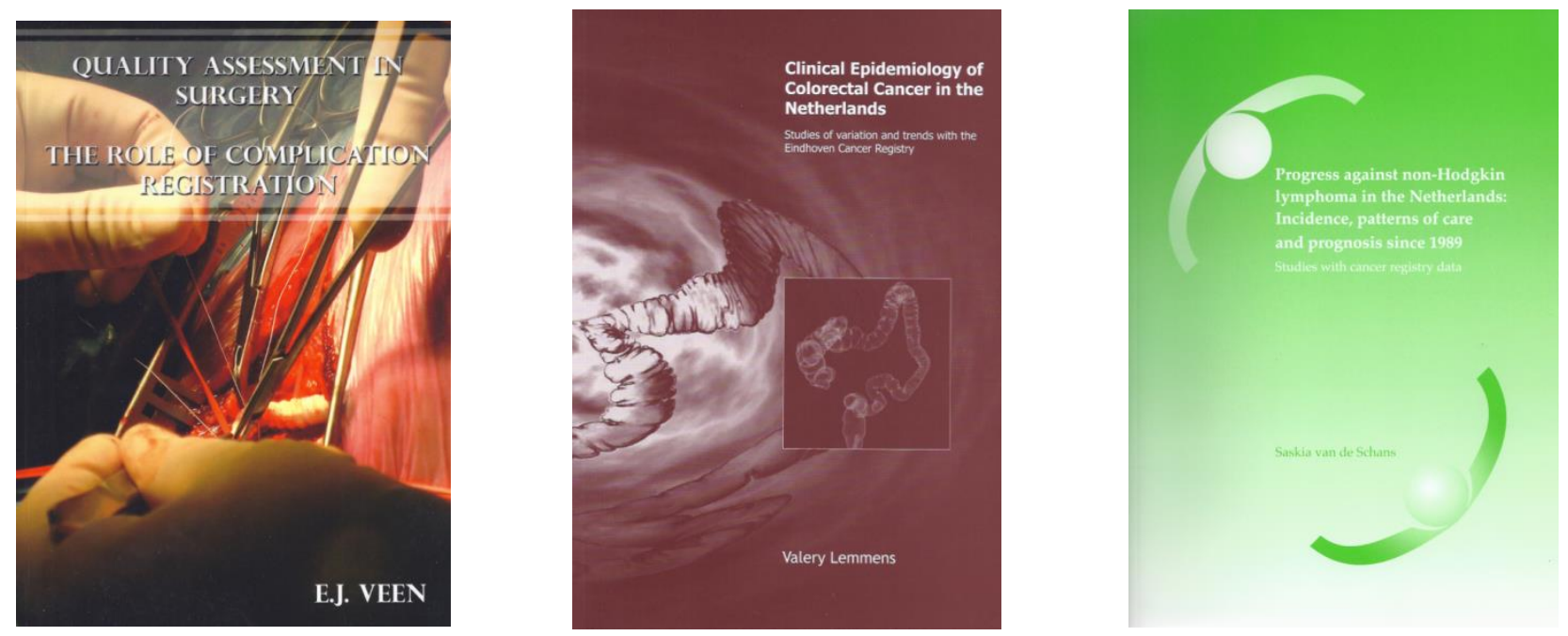

Mijn eerdere promovendus Eelco Veen heeft laten zien hoe belangrijk het is om inzicht te hebben in complicaties van behandeling. Mijn 1e promovendus Valery Lemmens heeft o.a. laten zien dat ouderen met bepaalde co-morbiditeit vaker postoperatieve complicaties hebben na operatie voor dikkedarmkanker.

Eén van mijn eerdere promovendi, Saskia van de Schans, heeft onder andere onderzoek gedaan naar oudere patiënten met een bepaald type lymfeklierkanker, het non-Hodgkin lymfoom. Ze liet o.a. zien dat minder dan de helft van de patiënten van 75 jaar of ouder de standaardbehandeling met CHOP chemotherapie ontving. Ondanks het feit dat vooral de fitte ouderen werden geselecteerd voor deze zware behandeling, had 2/3 van de patiënten last van ernstige complicaties en kon slechts een kwart van de patiënten de ingezette behandeling afmaken.

Eenzelfde soort resultaten bij oudere patiënten met longkanker kwam uit een onderzoek van één van mijn huidige promovendi, Lizzy Driessen. Uit klinisch onderzoek bij voornamelijk jongere en fitte patiënten met stadium III niet-kleincellig longkanker blijkt dat een behandeling met gelijktijdige chemotherapie en radiotherapie (de chemoradiotherapie) de beste overlevingskans geeft. Deze behandeling gaat echter ook gepaard met veel complicaties. Onduidelijk is nog hoe oudere en kwetsbare patiënten deze behandeling verdragen en wat het effect is op de overlevingstijd en kwaliteit van leven. Om hier inzicht in te krijgen is de dagelijkse praktijk in kaart gebracht in 3 grote ziekenhuizen (VieCuri Medisch Centrum, Zuyderland ziekenhuis lokatie Heerlen en het Maastricht Universitair Medisch Centrum). 
Het bleek dat slechts een derde van alle 70 plussers de standaardbehandeling van gelijktijdige chemoradiotherapie ontving. Bijna een kwart ontving chemotherapie gevolgd door radiotherapie, $16 \%$ ontving alleen radiotherapie en ruim een kwart ontving geen antikankerbehandeling. Met name patiënten van 75 jaar of ouder, degenen met een slechte performance status en patiënten met ernstige comorbiditeit ontvangen minder vaak een behandeling met chemoradiotherapie.

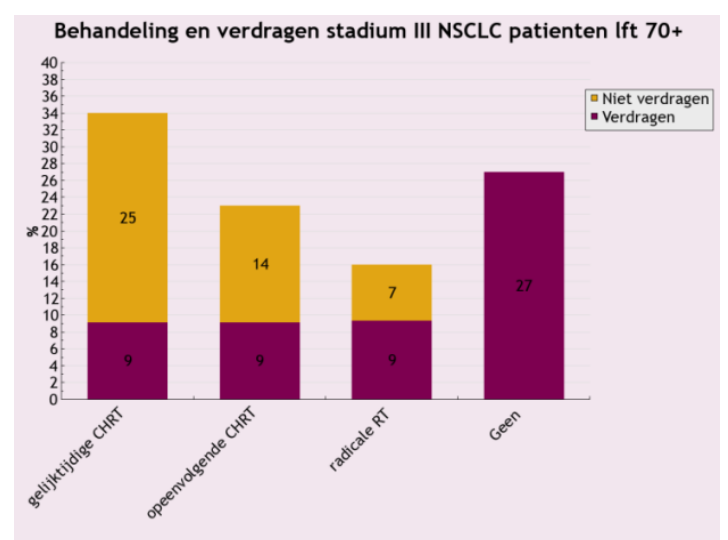

Ondanks deze strenge selectie van de meest fitte ouderen voor chemoradiotherapie, werd gelijktijdige chemoradiotherapie slecht verdragen: slechts een vierde van de patiënten had geen ongeplande ziekenhuisopname en kon de behandeling afmaken vergeleken met $40 \%$ van de patiënten die opeenvolgend chemotherapie en radiotherapie ontvingen en $60 \%$ van de patiënten die alleen bestraald werden. Chemoradiotherapie werd nog aanzienlijk slechter verdragen als ernstige co-morbiditeit aanwezig was (respectievelijk slechts $12 \%$ en $23 \%$ kon gelijktijdige respectievelijk opeenvolgende chemoradiotherapie verdragen).

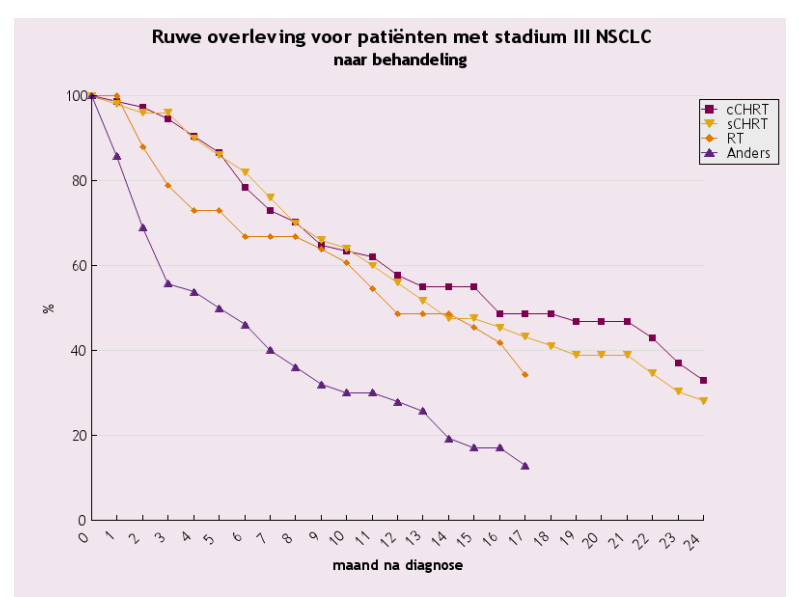

Ook werd de overleving van deze patiënten in kaart gebracht. De figuur geeft de overleving van weer per type behandeling. Op de y-as staat het percentage dat in leven is en op de $x$ as de tijd na diagnose van longkanker. Op tijdstip 0 (diagnose) is iedereen nog in leven; de overleving is $100 \%$. We zien dat van de patiënten die geen antikankerbehandeling ontvingen, bijna de helft na 3 maanden overleden was. Dit is geen onverwacht resultaat, aangezien dit de meest kwetsbare patiënten zijn, waar niet voor niets geen antikankerbehandeling meer is gestart. De overleving is duidelijk beter voor patiënten die wel een antikankerbehandeling hebben ontvangen. Echter, ondanks de strenge selectie van de meest fitte ouderen voor gelijktijdige chemoradiotherapie, was de overleving niet aantoonbaar beter dan opeenvolgende chemoradiotherapie en zelfs niet beter dan alleen bestraling. Aangezien gelijktijdige chemoradiotherapie wel aanzienlijk meer complicaties met zich meebrengt, betekent dit dat het van groot belang is om na te gaan welke patiëntkarakteristieken kunnen voorspellen of een oudere patiënt zulke ingrijpende behandeling kan verdragen en hier ook profijt van kan hebben. Dit zijn we o.a. aan het onderzoeken in de ELDAPT-trial, een groot multicenteronderzoek in samenwerking met de MAASTRO Clinic en MUMC+. 
Dan zijn we aangekomen bij de volgende letter van 'ACTIE'. Saburo Shochi kwam in 2012 op een andere manier in actie. Hij vestigde een wereldrecord toen hij met zijn 106 jaar als oudste in de wereld een wereldrondreis maakte met behulp van het openbaar vervoer. Hij legde bijna $57.000 \mathrm{~km}$ af. Hij ging heel duidelijk buiten de grenzen van zijn eigen wereldje.

Dat is ook van belang bij de T in ACTIE. Die staat namelijk voor Transmurale samenwerking. Bij transmurale samenwerking kijk je buiten de grenzen van de eigen instelling. In feite betekent dit dat er sprake is van samenwerking tussen verschillende

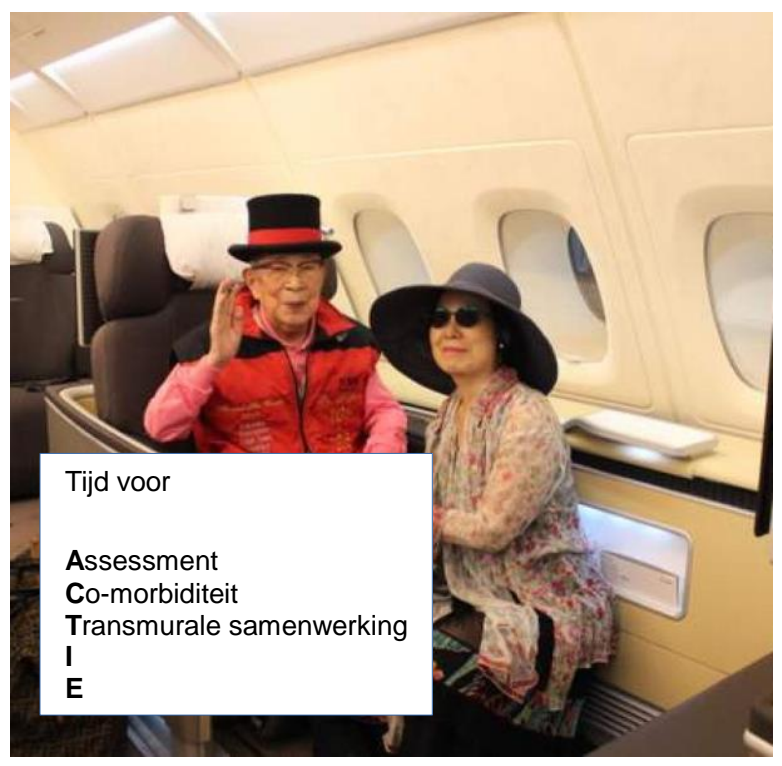
werelden, de zogenaamde tweede lijn (het ziekenhuis) en de eerste lijn (o.a. huisartsen, fysiotherapeuten, diëtisten, specialisten ouderengeneeskunde).

Transmurale samenwerking is onder andere van belang bij een nazorgplan dat we hebben opgezet voor oudere patiënten met dikkedarmkanker. Oudere patiënten, en met name degenen met co-morbiditeit, sterven vaker na een operatie voor dikkedarmkanker.

Daarnaast blijkt dat er voor ouderen na deze ingreep ook ná de postoperatieve periode in het eerste jaar na operatie een oversterfte is ten opzichte van jongeren, zelfs als rekening wordt gehouden met het feit dat ouderen in de algemene bevolking een hogere sterftekans hebben dan jongeren. We weten eigenlijk nog steeds niet, waar dit door komt. Deze patiënten hebben de postoperatieve periode doorstaan. Na ontslag uit het ziekenhuis loopt signalering van achteruitgang vooral via de huisarts. Daarom is het van belang dat er een goede transmurale samenwerking is tussen het ziekenhuis en de huisarts. In het kader hiervan hebben we, samen met klinisch geriater Huub Maas uit het Elisabeth-

TweeStedenziekenhuis in Tilburg en de huisartsencoöperaties, een proactief nazorgplan opgezet in de regio's Venlo en Tilburg. Hierbij wordt proactieve nazorg geleverd door middel van huisbezoeken vanuit de huisartsenpraktijk. Bij ontslag van de patiënt uit het ziekenhuis krijgt de huisarts een hulpinstrument toegestuurd om op een gestructureerde manier naar de hele patiënt te kijken, dus niet alleen naar de dikkedarmkanker. Bij mogelijke problemen kan op deze manier snel actie worden ondernomen. Patiënten werden actief bij dit project betrokken. Zij gaven o.a. aan dat ze een goede transmurale samenwerking en snelle contacten bij mogelijke problemen als zeer belangrijk ervaren en dat het vooral ook belangrijk is om de transmurale samenwerking uit te stralen naar de patiënt.

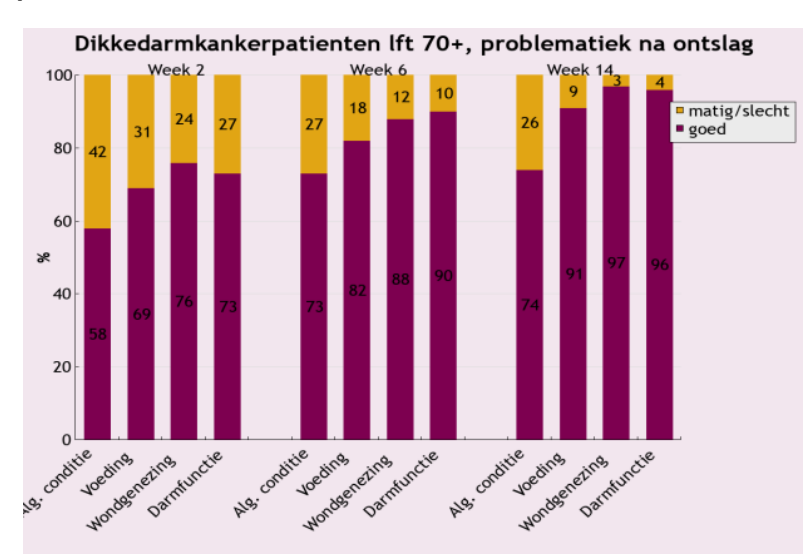

In dit project werd de gezondheid van de patiënt in kaart gebracht in week 2, 6 en 14 na ontslag. Belangrijke onderdelen, waarnaar werd gekeken door de huisarts waren de 'algemene conditie', 'voeding', 'wondgenezing' en 'darmfunctie'. We zagen dat er op alle onderdelen een duidelijke vooruitgang was in de tijd na ontslag, maar bij ruim een kwart van de patiënten bleef de algemene conditie nog lange tijd na operatie matig tot slecht. Zo gaf ook bijna $30 \%$ van de patiënten aan 5 maanden na de operatie nog steeds moe te 
zijn. Promovendus Maarten van Heinsbergen heeft laten zien dat het merendeel van de patiënten die worden geopereerd voor dikkedarmkanker ook op de lange termijn nog last heeft van darmklachten, die weer een negatieve invloed hebben op de kwaliteit van leven. Dat betekent dat het belangrijk is om na te gaan hoe deze klachten zoveel mogelijk kunnen worden voorkomen, maar ook dat patiënten goed geïnformeerd moeten worden over wat hun te wachten staat. Dat brengt me op de volgende letter van ACTIE.

Agnes was ruim een jaar geleden in het nieuws. Ze was met haar 102 jaar de oudste lerares. Toen ze 80 was hadden ze op de school waar haar dochter werkzaam is een lerares huishoudkunde nodig. Agnes heeft dat toen opgepakt en doet dat nog steeds met veel plezier.

De I in ACTIE staat voor Informeren. Het is dus heel belangrijk om patiënten te informeren over wat

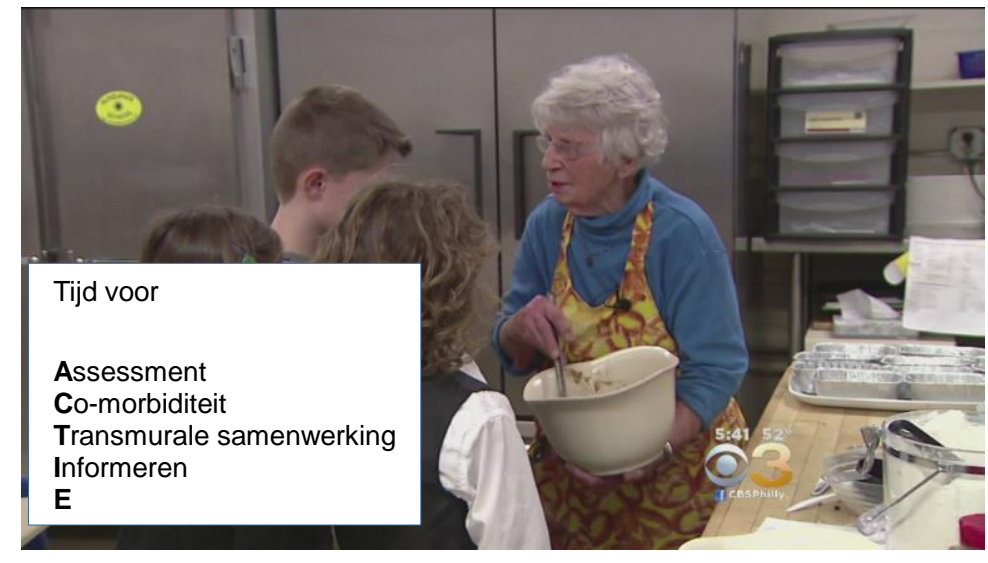
hun te wachten staat, zowel op de korte als lange termijn na de behandeling. Daarnaast beogen we met de resultaten van het onderzoek binnen mijn leerstoel informatie te vergaren, waarmee een betere inschatting kan worden gemaakt welke patiënten het risico lopen ernstige bijwerkingen te ontwikkelen en welke patiënten voordeel kunnen hebben van een bepaalde behandeling. Deze informatie kan vervolgens weer worden gebruikt om patiënten te informeren en kan als ondersteuning dienen bij het kiezen van een behandeling die het beste past bij de betreffende patiënt.

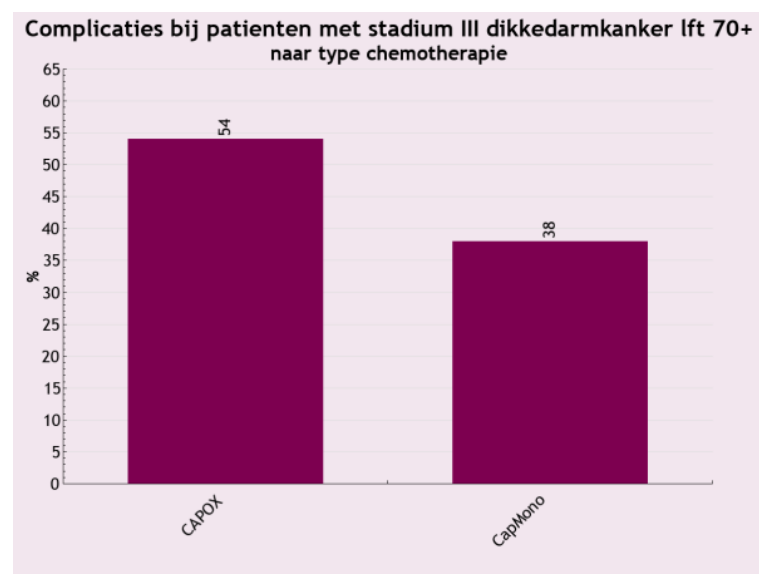

Zo heeft promovendus Felice van Erning onderzoek gedaan naar twee soorten chemotherapie voor dikkedarmkanker. De geadviseerde behandeling voor stadium III dikkedarmkanker is operatie gevolgd door chemotherapie. Felice vergeleek 2 soorten chemotherapie, te weten CAPOX en Capecitabine monotherapie (CapMono). Ze liet zien dat de kans op ernstige complicaties anderhalf maal zo hoog was bij de groep die met CAPOX behandeld werd.

Daarnaast liet ze zien dat er geen verschil was in overleving tussen de twee soorten chemotherapie. Aan de hand van deze informatie wordt nu dus vaker overwogen om oudere patiënten na de operatie aanvullend te behandelen met CapMono in plaats van CAPOX.

We hebben het tot nu toe vooral gehad over behandelingen meteen na de diagnose van kanker. Helaas is het nog steeds niet zo dat alle patiënten met kanker overleven. Een deel zal dus aan de kanker overlijden. In de laatste fase is het vooral van belang dat niet alleen de kwaliteit van leven, maar ook de kwaliteit van sterven zo optimaal mogelijk is. In de praktijk komt het voor dat patiënten in deze fase te lang worden doorbehandeld. Promovendus Marleen Moors doet hier onderzoek naar. Juist voor deze patiënten is het van belang om goed en tijdig geïnformeerd te worden over de doelen en effecten van wel/niet behandelen. Ook is in deze fase de eerder genoemde transmurale samenwerking van uitermate groot belang. 


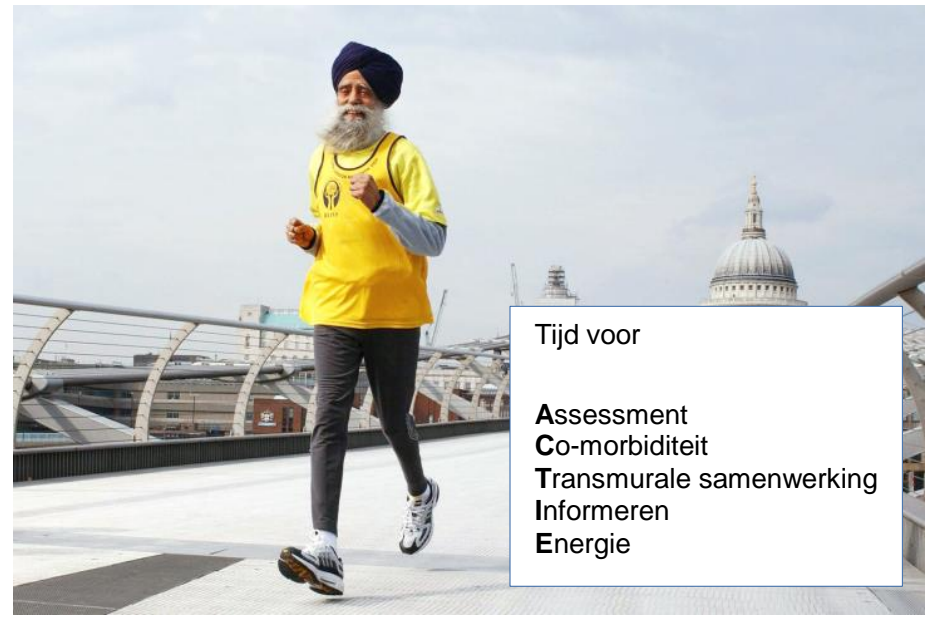

Dan kom ik op de laatste letter van ACTIE. Deze is zeker van toepassing op meneer Sing. Hij kwam in 2012 in het nieuws toen hij als 100-jarige nog een marathon had uitgerend. Inmiddels is hij 105 en ook vorig jaar rende hij nog een marathon op 104-jarige leeftijd. Meneer Singh is op 81-jarige leeftijd begonnen met langeafstandslopen. Hij lijkt voldoende energie te hebben!

De E van ACTIE staat voor Energie. Ik heb net laten zien dat veel oudere patiënten nog lange tijd na behandeling van kanker last hebben van de gevolgen, met name moeheid.

Voor patiënten die worden behandeld voor kanker is in Nederland een nazorgprogramma (de oncologische revalidatie) beschikbaar dat o.a. bestaat uit het verbeteren van de conditie/fitheid. Dat is heel mooi! Het zou echter nog mooier zijn als we het verbeteren van de conditie zo vroeg mogelijk starten. Voor patiënten met kanker betekent dit dus bij voorkeur al starten vóór de behandeling van de kanker en continueren tijdens en na de behandeling. Op die manier krijgen patiënten meer energie en gaan ze fitter de behandeling in. Hierdoor krijgen ze naar verwachting minder complicaties en kunnen ze de behandeling vaker afmaken. Ook zal hierdoor het herstel sneller gaan, de sterfte afnemen en de conditie, en daarmee de kwaliteit van leven beter zijn. Kortom, ook na behandeling hebben ze naar verwachting meer energie.

Aangezien spieropbouw niet lukt zonder de juiste bouwstenen, kan dit het beste worden gerealiseerd in combinatie met een goed voedingsadvies. Indien van toepassing, is ook stoppen met roken van belang.

Dit lijkt niet moeilijk, maar toch is dit in de praktijk niet zo gemakkelijk. Ten eerste wordt het verbeteren van de conditie voor aanvang van de behandeling voor kanker nog niet vergoed door zorgverzekeraars, ondanks het feit dat eerder onderzoek bij o.a. patiënten die een hartoperatie ondergaan heeft aangetoond dat er per patiënt een kostenbesparing is vanwege minder complicaties, een kortere ligduur en een sneller herstel. Ten tweede is het de vraag hoe patiënten gemotiveerd kunnen worden om een verandering van leefstijl te starten en vooral ook om deze vol te houden. Oudere patiënten zijn vaak kwetsbaar en moeten al zo veel in de tijd van diagnose en behandeling van kanker. Deze kwetsbare patiënten hebben er mogelijk voordeel bij als een beweegprogramma thuis plaatsvindt onder begeleiding van een fysiotherapeut. Dan kan met de patiënt worden gekeken wat hij/zij kan en ook leuk vindt om te doen. Anders houdt iemand het niet vol om te blijven bewegen. Een programma kan dan zoveel mogelijk worden ingebouwd in het dagelijks leven. Ook van belang is dat op deze manier de familie en de omgeving erbij kunnen worden betrokken, hetgeen helpt om de motivatie te vergroten.

Ik heb eerder in deze rede al laten zien dat de behandeling voor longkanker zwaar is met veel complicaties. Hierdoor kunnen veel oudere patiënten de ingezette behandeling niet afmaken. Oncologie-fysiotherapeut Marieke Peters en promovendus Lizzy Driessen hebben samen een literatuuronderzoek gedaan naar een beweegprogramma voor patiënten met longkanker in de thuissituatie. Uit deze studies bleek dat de conditie verbeterde door de beweegprogramma's. Verder hielden patiënten het programma beter vol in geval ze begeleid werden en als een persoonlijk programma was opgesteld. Het onderzoek toonde echter ook aan dat er nog te weinig werd beschreven over het effect 
van zo'n beweegprogramma op het doorstaan van de behandeling van longkanker om conclusies te kunnen trekken.

Aangezien er dus nog weinig kennis is over dit onderwerp, zullen we binnen mijn leerstoel niet alleen onderzoek uitvoeren met betrekking tot transmuraal en multidisciplinair onderzoek naar de effecten van leefstijlinterventies op het doorstaan van de behandeling van kanker en op de overleving en kwaliteit van leven, maar met name ook naar de haalbaarheid en het volhouden van deze programma's door oudere patiënten met kanker. Deels zal dit onderzoek worden gedaan met behulp van gegevens van de EnCoRe-studie van Matty Weijenberg. Doel is dat patiënten zowel tijdens als na de behandeling meer energie zullen hebben en daarmee een betere kwaliteit van leven.

Dan wil ik hier nog een wijze les van meneer Singh geven. Voor een goede kwaliteit van leven is volgens hem het volgende van belang: "Ben dankbaar voor alles wat je hebt, blijf weg bij 'negatieve' mensen, blijf rennen en blijf lachen". Hopelijk kunnen ouderen op deze manier blijven stralen!

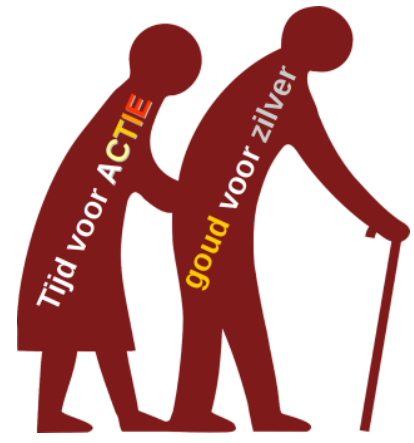

Dit brengt me weer terug bij de titel van deze rede 'Tijd voor ACTIE: goud voor zilver'. Ik heb uitgebreid gesproken over de vergrijzing. Ik zou liever het woord 'grijs' vervangen door 'zilver'. Dat straalt veel meer. Met de resultaten van het onderzoek binnen mijn leerstoel willen we bijdragen aan de beste de zorg voor ouderen met kanker. We gaan voor de gouden medaille op het gebied van de zorg voor de zilveren populatie, dus: "goud voor zilver". 


\section{Dankwoord}

Ik zou mijn werk niet kunnen doen zonder de expertise van en prettige samenwerking met velen. Ik wil hier geen poging doen om alle namen te noemen. De figuur spreekt voor zich. Ik ben jullie enorm dankbaar. Wat is het mooi om samen mijlpalen te bereiken!

Een aantal bijzondere mensen wil ik echter wel noemen.

Allereerst wil ik graag de leden van het College van Bestuur van de Universiteit Maastricht, evenals de leden van mijn College van Toezicht en de Raden van Bestuur van Maastricht Universitair Medisch Centrum en VieCuri Medisch Centrum bedanken voor het in mij gestelde vertrouwen en het mogelijk maken van deze leerstoel.

Professor Frans Ramaekers, professor Matty Weijenberg en professor Piet van den Brandt, jullie wil ik danken voor jullie blijvende vertrouwen in mij. Jullie hebben ervoor gezorgd dat deze leerstoel gerealiseerd kon worden.

Professor Jan Willem Coebergh, jij hebt aan de wieg gestaan van mijn carrière en hebt mij als het ware groot gebracht in het doen van goed wetenschappelijk onderzoek op het gebied van kanker, en met name kanker bij ouderen. Volgens mij kunnen twee personen in karakter niet meer verschillen dan wij twee, maar we kunnen heel goed samenwerken en hebben samen heel veel gerealiseerd. Dank voor al je steun en je niet-aflatende vertrouwen in mij. Zonder jou had ik hier zeker niet gestaan.

Mijn promovendi zijn de afgelopen 45 minuten de revue al gepasseerd. Valery, Eelco, Saskia, Huub, Felice, Sander, Roy, Lizzy, Maarten en Marleen. Jullie zijn allemaal heel verschillend, zowel qua opleiding als qua persoon. Ik vind het uitermate boeiend om met jullie samen te werken. Jullie opleiden maakt mijn werk interessant!

Professor Sef Heijnen, voor mij ome Sef, mijn jongste oom van vaders kant. Hoewel je professor bent in een heel ander vakgebied, vond ik het fijn om te kunnen sparren toen ik overwoog of ik de stap tot hoogleraar wilde zetten. Afgelopen november is je afscheidscollege geweest, dus we volgen elkaar zo'n beetje op. Ik vind het geweldig dat je vandaag aan het cortège deelneemt.

Gonnie en Dave, mijn schoonzus en schoonbroer: ik vind het leuk om met jullie over heel andere dingen te praten dan mijn vakgebied. Ook leuk trouwens om mascotte te zijn bij de muziekquiz!

Edith en Twan, jullie zijn iets verder weg familie, maar ik beschouw jullie ook echt als mijn schoonzus en schoonbroer. Jullie zijn bij alle belangrijke en ook minder belangrijke gebeurtenissen in mijn leven aanwezig, en weten overal iets speciaals van te maken.

Carina en Bert, mijn zus en schoonbroer. Met jullie kan ik altijd alles delen. Op leuke, maar ook op moeilijke en spannende momenten staan jullie voor me klaar en jullie weten op de juiste momenten te relativeren. 
Marijke en Dré, mijn ouders en Jo en Tun, mijn schoonouders. Jullie hebben me altijd gesteund in mijn keuzes. Zelfs toen ik bijvoorbeeld als alternatief voor geneeskunde ideeën had om de opleiding tot industrieel vormgever of bouwkunde te gaan volgen, namen jullie mijn plannen serieus en gingen met mij naar de open dagen. Jullie vonden het vooral van belang dat ik iets ging doen wat ik leuk vond. Tijdens mijn hele carrière leven jullie steeds heel erg met mij mee en tijdens mijn fietstochtjes met Pap kunnen we heerlijk hierover filosoferen.

Mijn neefjes en nichtjes Aline, Giel, Sanne, Masja en Liam, en inmiddels de uitbreiding met Yannick en Beau. Ja, jullie tante is nu professor. Dat vinden jullie wel grappig, maar ook heel erg gaaf. Dank voor de heerlijke afleiding die jullie me bezorgen!

Bert, wij voelen elkaar enorm goed aan en hebben daardoor weinig woorden nodig om elkaar te begrijpen. Daarom spreek ik hier ook weinig woorden. Je weet wat ik bedoel en ik ben ervan overtuigd dat je ervoor zorgt dat ik ook in deze nieuwe functie met beide benen op de grond blijf staan.

Ik heb gezegd. 